\title{
Selective Synthesis of Benzimidazoles from $o$-Phenylenediamine and Aldehydes Promoted by Supported Gold Nanoparticles
}

\author{
Marina A. Tzani ${ }^{1}$, Catherine Gabriel ${ }^{2}$ and Ioannis N. Lykakis ${ }^{1, *(\mathbb{D})}$ \\ 1 Department of Chemistry, Aristotle University of Thessaloniki, University Campus, \\ 54124 Thessaloniki, Greece; marina_tzani@hotmail.com \\ 2 HERACLES Research Center, KEDEK, Laboratory of Environmental Engineering (EnvE-Lab), \\ Department of Chemical Engineering, AUTH, 54124 Thessaloniki, Greece; katerinagabriel79@gmail.com \\ * Correspondence: lykakis@chem.auth.gr; Tel./Fax: +30-2310-997871
}

Received: 1 November 2020; Accepted: 29 November 2020; Published: 1 December 2020

\begin{abstract}
We investigated the catalytic efficacy of supported gold nanoparticles (AuNPs) towards the selective reaction between $o$-phenylenediamine and aldehydes that yields 2-substituted benzimidazoles. Among several supported gold nanoparticle platforms, the $\mathrm{Au} / \mathrm{TiO} \mathrm{O}_{2}$ provides a series of 2-aryl and 2-alkyl substituted benzimidazoles at ambient conditions, in the absence of additives and in high yields, using the mixture $\mathrm{CHCl}_{3}: \mathrm{MeOH}$ in ratio 3:1 as the reaction solvent. Among the AuNPs catalysts used herein, the $\mathrm{Au} / \mathrm{TiO}_{2}$ containing small-size nanoparticles is found to be the most active towards the present catalytic methodology. The $\mathrm{Au} / \mathrm{TiO}_{2}$ can be recovered and reused at least five times without a significant loss of its catalytic efficacy. The present catalytic synthetic protocol applies to a broad substrate scope and represents an efficient method for the formation of a $\mathrm{C}-\mathrm{N}$ bond under mild reaction conditions. Notably, this catalytic methodology provides the regio-isomer of the anthelmintic drug, Thiabendazole, in a lab-scale showing its applicability in the efficient synthesis of such $N$-heterocyclic molecules at industrial levels.
\end{abstract}

Keywords: gold nanoparticles; benzimidazoles; cyclization reaction; heterogeneous catalysis; $o$-phenylenediamine; thiabendazole

\section{Introduction}

Benzimidazole or $1 H-1,3$-benzodiazole-based heterocycles are structurally similar to naturally occurring nucleotides, i.e., adenine base of the DNA, as well as a component of vitamin $B_{12}$, and have extensively been used in drug synthesis and medicinal chemistry (Figure 1) and display a wide range of biological and clinical applications [1-6]. Benzimidazoles can easily interact with the biopolymers of the living systems, which are responsible for their numerous biological activities and functions. In particular, benzimidazole derivatives exhibit antimicrobial [7-9], antiviral [10,11], anticancer [12-14], anti-inflammatory [15-17], and antioxidant [18] activities, whereas various derivatives have been developed as therapeutic agents, such as proton pump inhibitors [2], level modulators [19], and antidiabetics (Figure 1) [20,21].

In general, two main traditional synthetic routes produce benzimidazole derivatives. The first route involves the coupling between $o$-phenylenediamine with carboxylic acids or their derivatives (nitriles, amides, esters, chlorides) [22-24]. The second route involves condensation reactions between $o$-phenylenediamine and aldehydes or alcohols via a dehydrogenated coupling, followed by oxidative cyclodehydrogenation [24,25], but in many of these methods, a stoichiometric amount of oxidizing agents is a prerequisite (Scheme 1) [26-29]. Other methods such as thermal- or acid-promoted 
synthesis as well as microwave, sonicator, or ultrasound methods are also known [24]. Interestingly, the direct regioselective C-2 arylation of imidazole with aryl halides typically requires the use of a $\mathrm{Pd}(\mathrm{II}) / \mathrm{Cu}(\mathrm{I})$ catalytic system in a large excess of reagents in the presence of additives, high temperature, or pressure [30].

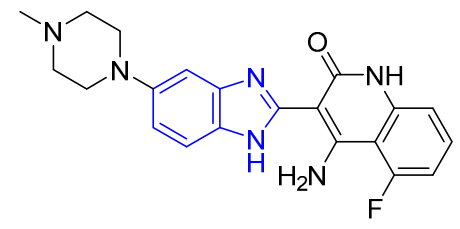

Dovitinib EGFR-3 inhibitor

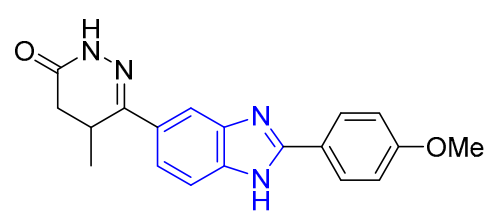

Pimobendan

Calcium sensitizer drug<smiles>c1ccc2[nH]c(-c3cncs3)nc2c1</smiles>

Thiabendazole Anthelmintic drug

Figure 1. Benzimidazole derivatives with biological activity.

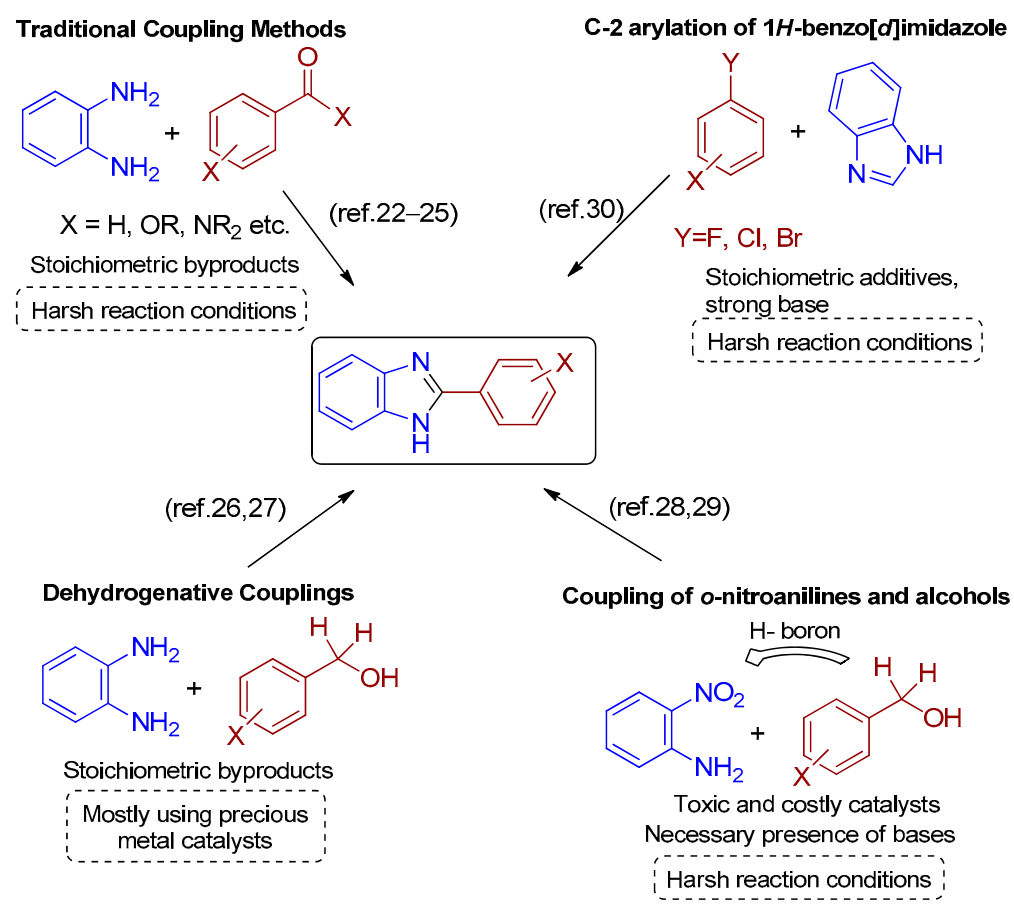

Scheme 1. Strategies toward the synthesis of 2-aryl-benzimidazoles.

To date, the emphasis is given to developing new, efficient, and "green" methods for the conversion of $o$-phenylenediamine and aldehydes to benzimidazole derivatives. Several heterogeneous catalytic systems that involve inorganic salts [31-34], zeolites [35-37], heterogeneous ionic liquid gel [38], micelles [39], and metal oxides [40-49] have been reported (Scheme S1). This transformation can be also achieved via photocatalytic processes in the presence of photosensitized molecules or semiconductor materials (Scheme S2) [50-56]. In recent years, the synthesis of supported metal nanoparticles as well as their applications, especially in catalysis, is of great interest for further study [57-60]. Among them, supported gold nanoparticles (AuNPs) have received considerable attention as powerful heterogeneous catalysts in several organic reactions. Interestingly, AuNPs have a small size which provides distinct physical properties and high reactivity [61], and overcome drawbacks of homogeneous gold catalysts. In specifics, AuNPs are not sensitive to air or moisture, promote the reactions under mild conditions, and exhibit high selectivity even in complicated reactions [62]. Several inorganic and organic materials have been used as heterogeneous supports which can disperse and stabilize AuNPs, provide active sites at the metal-support boundary, and influence the oxidation state of gold, thus allowing easy 
handling and the possibility of recovery [63]. These features have made AuNPs of great importance in the synthesis of heterocycles [64-67].

So far, Ruiz et al. reported the one-pot synthesis of 2-aryl-benzimidazoles from alcohols and diamines in the presence of $\mathrm{Au} / \mathrm{CeO}_{2}$ nanoparticles in trifluorotoluene at $90{ }^{\circ} \mathrm{C}$ (Scheme 2) [68]. The $\mathrm{Au} / \mathrm{CeO}_{2}$ has been reported as an excellent catalyst for the one-pot synthesis of benzimidazoyl quinoxaline derivatives from the cyclo-condensation of glyceraldehyde and $o$-phenylenediamine derivatives, followed by oxidative coupling with a different $o$-phenylenediamine derivative (Scheme 2) [69]. Tang et al. described the synthesis of 2-aryl-benzoxazoles and benzimidazoles from 2-nitrophenol or 2-nitroaniline, respectively, and alcohols via two hydrogen-transfer processes catalyzed by $\mathrm{Au} / \mathrm{TiO}_{2}$ in toluene or water at $130-150{ }^{\circ} \mathrm{C}$ [70]. Of note is that only the synthesis of 2-phenyl-1H-benzo[ $d$ ]imidazole was described using $\mathrm{Au} / \mathrm{TiO}_{2}$ in toluene or water at $150{ }^{\circ} \mathrm{C}$ under $\mathrm{N}_{2}$ atmosphere (Scheme 2). Additionally, AuNPs/SBA material was successfully applied for the synthesis of a series of 2-aryl-2,3-dihydroquinazoli-4(1H)-ones, as a heterogeneous catalyst in the condensation reaction between 2-aminobenzamide and aromatic aldehydes (result not shown) [71]. In all cases, high temperatures and prolonged reaction time were necessary for reaction completion. Given the importance of this type of transformation and in terms of sustainability, the use of ambient and more eco-friendly heterogeneous conditions for the synthesis of 2-aryl and 2-alkyl benzimidazole derivatives continues to be a long-standing goal of chemical research. In light of our ongoing research directions on developing sustainable catalytic processes to construct $N$-heterocyclic organic molecules of high biological interest [72-74], and metal nanoparticle-catalyzed transfer hydrogenation processes for conversion of nitroarenes into amines [75-80], herein we report the synthesis of a library of 2-aryl and 2-alkyl benzimidazoles using $\mathrm{Au} / \mathrm{TiO}_{2}$ as a catalyst at ambient conditions (Scheme 2).

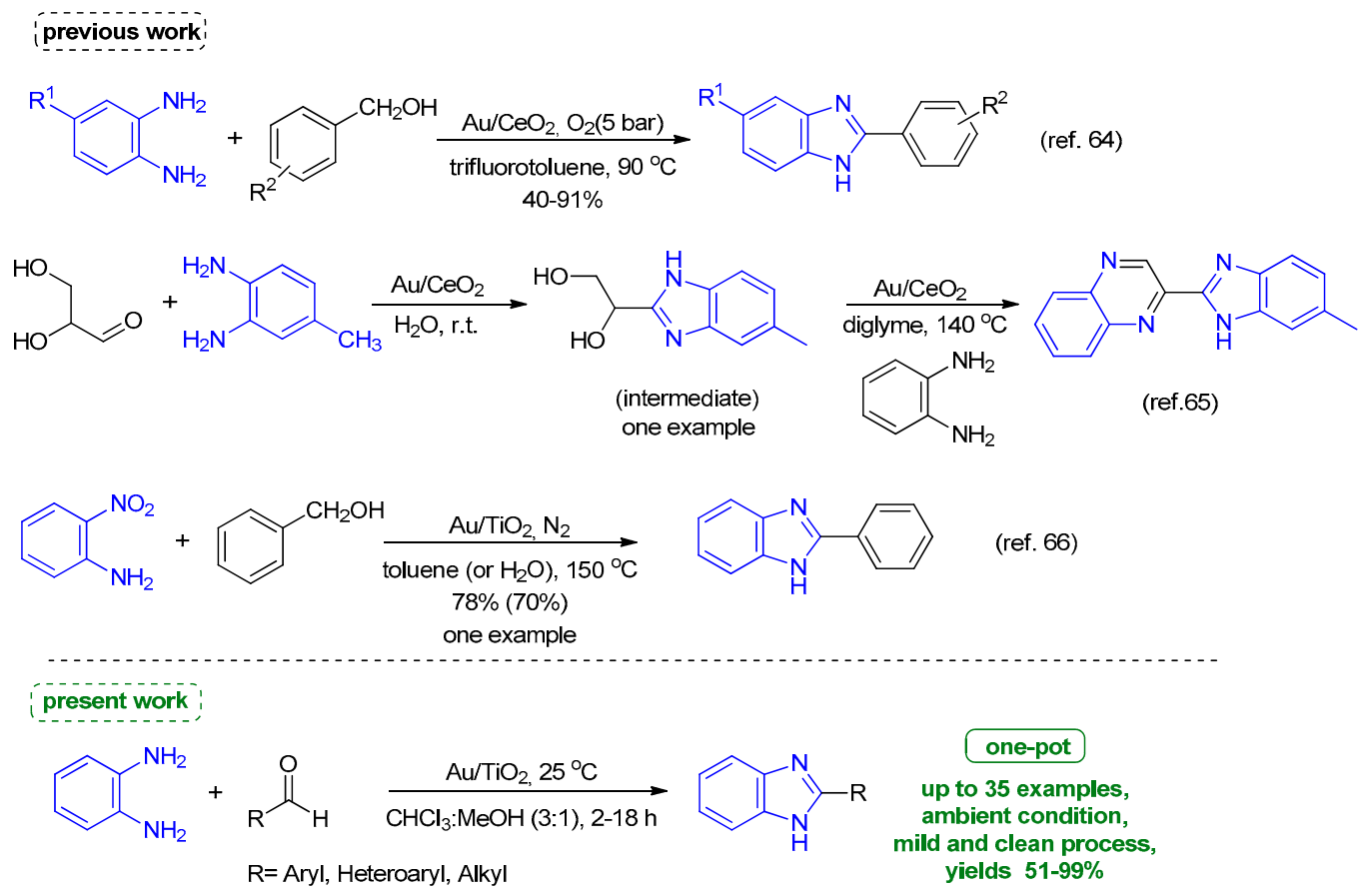

Scheme 2. Heterogeneous Au-catalyzed approaches for the synthesis of 2-substituted benzimidazoles.

\section{Materials and Methods}

\subsection{Materials}

For the catalytic reactions, we employed commercially available supported gold nanoparticles $\mathrm{Au} / \mathrm{TiO}_{2}, \mathrm{Au} / \mathrm{Al}_{2} \mathrm{O}_{3}$, and $\mathrm{Al} / \mathrm{ZnO}$, as well as the oxides $\mathrm{TiO}_{2}$ (Degussa P25 (Degussa Evonik GmbH, Essen, Germany, anatase/rutile $=3.6 / 1, \mathrm{BET}: 50 \mathrm{~m}^{2} \mathrm{~g}^{-1}$, nonporous), and $\mathrm{TiO}_{2} \mathrm{UV}-100$ (Hombikat, $100 \%$ anatase, 
BET: $\left.300 \mathrm{~m}^{2} \mathrm{~g}^{-1}\right), \mathrm{Al}_{2} \mathrm{O}_{3}$, and $\mathrm{SiO}_{2}$. The commercially available catalysts $\mathrm{Au} / \mathrm{TiO}_{2}, \mathrm{Au} / \mathrm{Al}_{2} \mathrm{O}_{3}$, and $\mathrm{Au} / \mathrm{ZnO}$ feature a ca. $1 \mathrm{wt} . \%$ Au loading and exhibit an average AuNP size of about 2-3 nm. All commercial heterogeneous catalysts and the salts $\mathrm{HAuCl}_{4}, \mathrm{AuCl}, \mathrm{AgNO}_{3}$, and $\mathrm{Cu}\left(\mathrm{ClO}_{4}\right)_{2} \cdot 6 \mathrm{H}_{2} \mathrm{O}$ were used without further purification. Catalysts with 1, 2, 3, and $5 \mathrm{wt} . \%$ Au loading on anatase mesoporous titania $\operatorname{Au} / \operatorname{MTA}(x), x=1,2,3$, and 5, were synthesized according to our previous works, where the deposition-precipitation method was used [76-78]. The products consist of a continuous network of tightly interconnected gold and anatase $\mathrm{TiO}_{2}$ nanoparticles and exhibit a large internal surface area (approximately 104-115 $\mathrm{m}^{2} \mathrm{~g}^{-1}$ ) and a narrow pore size distribution (approximately 7.3-7.5 nm), according to transmission electron microscopy (TEM), to the small-angle X-ray scattering (SAXS), and $\mathrm{N}_{2}$ physisorption measurements. Details on synthesis and characterization of the catalysts were described in reference [78]. The average Au particle size measured to be from 4.4 to 5.2 and from $7.1 \mathrm{~nm}$ to $9.4 \mathrm{~nm}$, while the gold loading was increased from $1 \%$ to $2 \%$ and from $3 \%$ to $5 \%$, respectively. Product analysis was conducted by ${ }^{1} \mathrm{H}$ NMR and ${ }^{13} \mathrm{C}$ NMR spectroscopy (Agilent AM 500 and Agilent AM 600, Agilent Technologies, Santa Clara, CA, USA). The identification of the products was realized by comparing the NMR spectra with those of the commercially available pure substances. LC-MS 2010 EV Instrument (Shimadzu, Tokyo, Japan) under Electrospray Ionization (ESI) conditions was used for the determination of the mass spectra. The reagents and solvents were purchased from Sigma-Aldrich (Merck KGaA, Darmstadt, Germany), and Fluorochem (Glossop, UK) and used without further purification. Thin-layer chromatography was performed on Millipore precoated silica gel plates $(0.20 \mathrm{~mm}$ thick, particle size $25 \mu \mathrm{m})$. Chemical shifts for ${ }^{1} \mathrm{H}$ NMR were reported as $\delta$ values and coupling constants were measured in hertz $(\mathrm{Hz})$. The following abbreviations were used for spin multiplicity: $\mathrm{s}=$ singlet, $\mathrm{brs}=$ broad singlet, $\mathrm{d}=$ doublet $\mathrm{t}=$ triplet, $\mathrm{q}=$ quartet, quin = quintet, $\mathrm{dd}=$ double of doublets, $\mathrm{ddd}=$ double doublet of doublets, and $\mathrm{m}=$ multiplet. Infusion experiments were carried out on an Agilent Q-TOF Mass Spectrometer, G6540B model with Dual AJS ESI-MS (Santa Clara, CA, USA). All the compounds (dissolved in LC-MS grade methanol) were introduced into the ESI source of the MS with a single injection of $15 \mu \mathrm{L}$ of the sample and with a flow rate of $300 \mu \mathrm{L} / \mathrm{min}$ of $100 \%$ methanol as a solvent in the binary pump. The experiments were run using a Dual AJS ESI source, operating in a positive ionization mode. Source operating conditions were $330{ }^{\circ} \mathrm{C}$ Gas Temp, 8 L/min Gas Flow, Sheath Gas Temp $250{ }^{\circ} \mathrm{C}$, Sheath Gas Flow $10 \mathrm{~L} / \mathrm{min}$, and $150 \mathrm{~V}$ Fragmentor. Data-dependent MS/MS analysis was performed in parallel with the MS analysis in a centroid mode, using different collision energies $(10,20,30,40 \mathrm{~V})$. All accurate mass measurements of the $[\mathrm{M}+\mathrm{H}]$ ions, or the corresponding major ions in some cases, were carried out by scanning from 100 to $500 \mathrm{~m} / \mathrm{z}$. The Q-TOF was calibrated $1 \mathrm{~h}$ prior to the infusion experiments by using a calibration mixture.

\subsection{Catalytic Reaction}

The appropriate supported gold catalyst $(1 \mathrm{~mol} \% \mathrm{Au}, 60 \mathrm{mg}$ of the solid material) was placed in a $5 \mathrm{~mL}$ glass reactor (vial), followed by the addition of solvent $\left(3 \mathrm{~mL}\right.$ ) or solvent mixture $\mathrm{CHCl}_{3}: \mathrm{MeOH}$ ( $3: 1,3 \mathrm{~mL})$, o-phenylenediamine $(0.3 \mathrm{mmol})$, and the aldehyde $(0.3 \mathrm{mmol})$. The reaction mixture was then stirred at $25^{\circ} \mathrm{C}$ (the temperature was maintained using a water bath) for $2 \mathrm{~h}$. The reaction was monitored by thin-layer chromatography (TLC) and after completion, the slurry was centrifuged to separate the solid catalyst from the reaction mixture and washed two times with $3 \mathrm{~mL}$ of ethanol. The filtrate was evaporated under vacuum to afford the corresponding products in pure form unless mentioned otherwise. Products, where needed, were purified by column chromatography on a silica gel using a gradient mixture of EtOAc-DCM to afford the desired 2-substituted benzimidazoles in good yields.

\subsection{Recycling Reaction}

Gold catalyst $\mathrm{Au} / \mathrm{TiO}_{2}(1 \mathrm{~mol} \% \mathrm{Au}, 40 \mathrm{mg}$ of the solid material) was placed in a $5 \mathrm{~mL}$ glass reactor (vial), followed by the addition of solvent mixture $\mathrm{CHCl}_{3}: \mathrm{MeOH}(3: 1,1.5 \mathrm{~mL})$, o-phenylenediamine $(0.2 \mathrm{mmol})$, and aromatic aldehyde $(0.2 \mathrm{mmol})$; the reaction mixture was then stirred at $25{ }^{\circ} \mathrm{C}$ 
(the temperature was maintained using water bath), for $2 \mathrm{~h}$. The reaction was monitored by thin-layer chromatography (TLC), and after completion, the slurry was centrifuged to separate the solid catalyst from the reaction mixture and washed three times with the aid of methanol (ca. $3 \mathrm{~mL}$ ). The filtrate was removed, the solvent was evaporated under vacuum, and the isolated product was determined by ${ }^{1} \mathrm{H}$ NMR without any chromatographic purification. The solid material was dried with the use of an oven at $100{ }^{\circ} \mathrm{C}$ for $12 \mathrm{~h}$ and used without any further purification for the next catalytic run.

\section{Results and Discussion}

\subsection{Evaluation of the Catalytic Conditions}

To optimize the reaction conditions, o-phenylenediamine (1) and 4-methylbenzaldehyde (2) were selected as model substrates. As a starting point, the initial control experiments, in the absence of a catalyst and in $1 \mathrm{~mL}$ of $\mathrm{MeOH}$ as solvent, showed the formation of the imine 3, as well as the formation of the desired 2-(4-methylphenyl)-1H-1,3-benzodiazole (4) and the 1-(4-methylbenzyl)-2-(4-methylphenyl)-1H-1,3-benzodiazole (5) in comparable yields, even at prolonged reaction time or in the presence of molecular sieves (Table 1, entries 1-4). Recently, a study on the synthesis of benzimidazoles with the use of methanolic solution and short reaction time was reported [81], contradicting the present observations. Additionally, in ethanol, the desired product 4 was formed even after $48 \mathrm{~h}$ in $70 \%$ yield, accompanied with $30 \%$ of the starting aldehyde 2 , as measured by ${ }^{1} \mathrm{H}$ NMR of the crude reaction mixture (Table 1, Entries 5 and 6). When the reaction took place in $\mathrm{CH}_{3} \mathrm{CN}$, similar results were measured with those observed in the case of the methanolic solution described above (Table 1, entries 7-10). In other solvents, such as 1,2-dichloroethane (1,2-DCE), ethyl acetate (EtOAc), and toluene, the corresponding imine 3 was formed as the only product (Table 1, entries 11, 13 and 15), while in $\mathrm{CHCl}_{3}$ and tetrahydrofuran (THF), a mixture of the products 3,4 , and 5 was observed (Table 1, entries 12 and 14). Even using a mixture of $\mathrm{CHCl}_{3}: \mathrm{MeOH}$ in different ratios, 1:1 and 3:1, no selective formation of the desired 4 was observed even after $18 \mathrm{~h}$ (Table 1, entries 16-18). The data summarized in Table 1, shows no selective synthesis of the desired imidazole 4 under the present conditions even at prolonged reaction time. Thus, we continue the development of the catalytic conditions using the above polar and non-polar solvents.

Based on these preliminarily results at the control experiments for the synthesis of the desired product 4, the development of the catalytic condition was further performed mainly in $\mathrm{MeOH}$ and $\mathrm{CH}_{3} \mathrm{CN}$ (Table S1). Thus, we initially studied the model reaction under homogeneous conditions in the presence of several salts $\left(20 \mathrm{~mol} \%\right.$ ), such as $\mathrm{HAuCl}_{4}$ and $\mathrm{AuCl}, \mathrm{AgNO}_{3}$, and $\mathrm{Cu}\left(\mathrm{ClO}_{4}\right)_{2} \cdot 6 \mathrm{H}_{2} \mathrm{O}$ in acetonitrile and methanol $(1 \mathrm{~mL})$ at room temperature within $18 \mathrm{~h}$. An equimolar amount of 1 and $2(0.1 \mathrm{mmol})$ was dissolved in the appropriate solvent in a $4 \mathrm{~mL}$ vial with an open Teflon cap, and the reaction mixture was stirred vigorously. After filtration of the reaction mixture over a short path of silica gel to withhold the catalyst amount and the solvent evaporation, the residue was dissolved in deuterium solvent (ca. $\mathrm{CDCl}_{3}$ ) and the reaction process was determined by ${ }^{1} \mathrm{H} \mathrm{NMR}$ of the corresponding organic residue. In all cases, mixture of the desired product 4 accompanied by significant amounts of the 5 and the imine $\mathbf{3}$ were observed (results are shown in Table S1).

Moreover, we studied the model reaction in the presence of heterogeneous surfaces such as $\mathrm{SiO}_{2}$, $\mathrm{Al}_{2} \mathrm{O}_{3}$, and $\mathrm{TiO}_{2}$ (Table S2, entries 1-7). We have observed that the acidic nature of these surfaces may influence the course of the reaction. When alumina was used as a catalyst in acetonitrile at $2 \mathrm{~h}$, the formation of imine intermediate 3 was observed in $44 \%$ yield accompanied by the desired product 4 in 38\% yield, as measured by ${ }^{1} \mathrm{H}$ NMR (Table S2, entry 2). Increasing the amount of alumina or the reaction time to $48 \mathrm{~h}$, we noticed a small increase in the yield of 4 (46\%) as the imine 3 decreased significantly (18\%) (Table S2, entry 3); while in methanol, the products 4 and 5 were formed in $40 \%$ and $60 \%$ yields, respectively (Table S2, entry 4). At the same content, titanium oxide led to the formation of the above products 4 and 5 , in the range of $59 \%$ to $39 \%$ in $\mathrm{MeOH}$ and $\mathrm{CH}_{3} \mathrm{CN}$, respectively (Table S2, entries 5-7). Based on literature work [50-53], where visible light with the presence of a semiconductor 
or a photosensitizer promoted the synthesis of benzimidazoles, herein the same reaction process was also tried under photochemical conditions, using a Xenon lamp (300 W, $\lambda>300 \mathrm{~nm}$ ), although no significant changes were observed for the yield of the desired product 4 (Table S2, entry 8).

Table 1. Solvent screening for the reaction between $\mathbf{1}$ and $\mathbf{2}$ in the absence of catalyst.
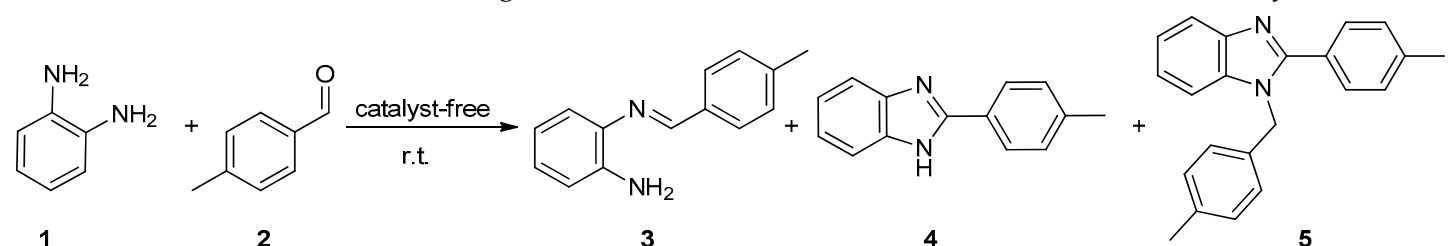

4

5

\begin{tabular}{|c|c|c|c|c|c|}
\hline Entry & Solvent ${ }^{a}$ & Time (h) & $3(\%)^{b}$ & $4(\%)^{b}$ & $5(\%)^{b}$ \\
\hline 1 & $\mathrm{MeOH}$ & 0.5 & 71 & 29 & - \\
\hline 2 & $\mathrm{MeOH}$ & 2 & 11 & 58 & 31 \\
\hline $3^{c}$ & $\mathrm{MeOH}$ & 2 & - & 48 & 59 \\
\hline 4 & $\mathrm{MeOH}$ & 48 & 13 & 55 & 32 \\
\hline 5 & $\mathrm{EtOH}$ & 2 & 71 & 29 & - \\
\hline $6^{d}$ & EtOH & 48 & - & 70 & - \\
\hline 7 & $\mathrm{CH}_{3} \mathrm{CN}$ & 0.5 & 95 & - & 5 \\
\hline 8 & $\mathrm{CH}_{3} \mathrm{CN}$ & 2 & 57 & 30 & 13 \\
\hline $9^{c}$ & $\mathrm{CH}_{3} \mathrm{CN}$ & 2 & - & 57 & 33 \\
\hline 10 & $\mathrm{CH}_{3} \mathrm{CN}$ & 48 & 15 & 59 & 26 \\
\hline 11 & 1,2-DCE & 2 & 100 & - & - \\
\hline 12 & $\mathrm{CHCl}_{3}$ & 2 & 16 & 24 & 60 \\
\hline 13 & EtOAc & 2 & 100 & - & - \\
\hline 14 & THF & 2 & - & 47 & 53 \\
\hline 15 & Toluene & 2 & 100 & - & - \\
\hline 16 & $\begin{array}{c}\mathrm{CHCl}_{3}: \mathrm{MeOH} \\
(1: 1)\end{array}$ & 2 & - & 41 & 59 \\
\hline 17 & $\begin{array}{c}\mathrm{CHCl}_{3}: \mathrm{MeOH} \\
(3: 1)\end{array}$ & 2 & 13 & 29 & 58 \\
\hline 18 & $\begin{array}{c}\mathrm{CHCl}_{3}: \mathrm{MeOH} \\
(3: 1)\end{array}$ & 18 & 5 & 57 & 38 \\
\hline
\end{tabular}

a Reaction conditions: $o$-phenylenediamine 1 (0.1 mmol), 4-methylbenzaldehyde 2 (0.1 mmol), solvent $(1 \mathrm{~mL})$. b Yields of 3, 4, 5 were determined by ${ }^{1} \mathrm{H}$ NMR from the crude reaction mixture. ${ }^{\mathrm{c}}$ In the presence of molecular sieves. ${ }^{\mathrm{d}} 30 \%$ of the corresponding aldehyde 2 remain intact.

Next, we switched to a series of different gold-supported catalysts, i.e., the commercially available $\mathrm{Au} / \mathrm{TiO}_{2}, \mathrm{Au} / \mathrm{Al}_{2} \mathrm{O}_{3}$, and $\mathrm{Au} / \mathrm{ZnO}$ nanoparticles $(1 \% \mathrm{w} / \mathrm{w} \mathrm{Au})$ containing nanoparticles with the size ranging between $2-3 \mathrm{~nm}$. In these cases, $0.1 \mathrm{mmol}$ of the starting compounds 1 and 2 were used with $20 \mathrm{mg}$ of the catalyst $(1 \mathrm{~mol} \%)$ in $1 \mathrm{~mL}$ of solvent and at $25{ }^{\circ} \mathrm{C}$. It is worth noting that a remarkable increase in the yield of the desired imidazole 4 was observed when methanol was used as a solvent (Table 2, entries 1-3), however, in the presence of $\mathrm{Au} / \mathrm{TiO}_{2}$, quantitative formation of the 4 was observed within $18 \mathrm{~h}$ (Table 2, entry 3). In addition, a series of polar and non-polar solvents were studied herein, i.e., $\mathrm{CH}_{3} \mathrm{CN}$, 1,2-DCE, EtOAc, and THF (Table 2, entries 4-10), however, no selective formation of the imidazole 4 was observed. Interestingly, in $\mathrm{CHCl}_{3}$, the 4 was formed in $94 \%$ yield within only $2 \mathrm{~h}$ (Table 2, entry 12), compared to the corresponding reactions in $\mathrm{EtOH}$ and $\mathrm{MeOH}$, where 4 was observed in 51\% and 37\% yields accompanied by a significant amount of the imine 3 (Table 2, entries 10 and 11). The same reaction process was also tried under photochemical conditions, using a white-LED apparatus $(10.5 \mathrm{~W}, \lambda>380 \mathrm{~nm})$, although, a mixture of the product 3,4 , and 5 was observed by ${ }^{1} \mathrm{H}$ NMR spectroscopy (Table 2, entry 13). Finally, a mixture of $\mathrm{CHCl}_{3}: \mathrm{MeOH}$ in 3:1 ratio was used, while maintaining a constant temperature of $25^{\circ} \mathrm{C}$, in the presence of the above heterogeneous catalysts (Table 2, entries 14-16). Under these conditions, product 4 was quantitatively formed using $\mathrm{Au} / \mathrm{TiO} 2$ and within only $2 \mathrm{~h}$ (Table 2, entry 14). In contrast, $\mathrm{Au} / \mathrm{Al}_{2} \mathrm{O}_{3}$ and $\mathrm{Au} / \mathrm{ZnO}$ led to the formation of 
4 in $75 \%$ and $58 \%$ yield, accompanied by a significant amount of the imine 3 in $25 \%$ and $42 \%$ yield, respectively (Table 2, entries 15 and 16). In addition, increasing the $\mathrm{Au} / \mathrm{TiO}_{2}$ amount from $20 \mathrm{mg}$ to $60 \mathrm{mg}$ did not affect the reaction selectivity (Table 2, entry 17). It is worth noting that the catalyst $\mathrm{Au} / \mathrm{MTA}(1)$ and Au/MTA(2) (4.4 and $5.1 \mathrm{~nm}$ of AuNPs) shows high activity and good selectivity for the synthesis of 4 with $91 \%$ and $85 \%$ yield, respectively (Table 2, entries 18 and 19). In contrast, using the $\mathrm{Au} / \mathrm{MTA}(3)$ and Au/MTA(5) catalysts with higher nanoparticle size (7.1 and $9.4 \mathrm{~nm}$ ), a mixture of 3, 4, and 5 was observed, with the desired 4 predominating in $54 \%$ and $44 \%$ yield, respectively (Table 2, entries 20 and 21). In addition, it is noted that the classical concept of nanoparticle concentration/size can play a role in the catalytic procedure [82]. These results indicate a decrease in the selectivity of the imidazole 4 synthesis while the size of the nanoparticle increases. Additionally, gold nanoparticles with small size $(<5 \mathrm{~nm})$ are promoted in the present reaction (Table 2, entries 18-21), whereas the support probably significantly influences the reaction process; with $\mathrm{TiO}_{2}$ (anatase) to be the most suitable rather than the mesoporous titania MTA, or $\mathrm{Al}_{2} \mathrm{O}_{3}$ and $\mathrm{ZnO}$ (Table 2, entries 1-3 and 14-16). This observation supports previous works on the selective reduction of nitroarenes into anilines, where supported AuNPs on $\mathrm{TiO}_{2}$, with nanoparticles in the range of $2-5 \mathrm{~nm}$, were the most active catalysts [77,78]. Additionally, a theoretical study on gold particle activity based on the formation of $\sigma$-holes, binding sites for Lewis bases, e.g., $\mathrm{CO}$ or $\mathrm{H}_{2} \mathrm{O}$, reported that the catalyst activity increases as the metal nanoparticle size decreases [83]. Similar behavior was observed using $\mathrm{Au} / \mathrm{Al}_{2} \mathrm{O}_{3}$ as the catalyst; however, reaction completion toward the synthesis of the desired benzimidazole 4 , along with the best catalytic activity, was observed in prolonged reaction time, $18 \mathrm{~h}$, as shown in Table S3.

Table 2. Reaction conditions development between 1 and 2 for the synthesis of 4.

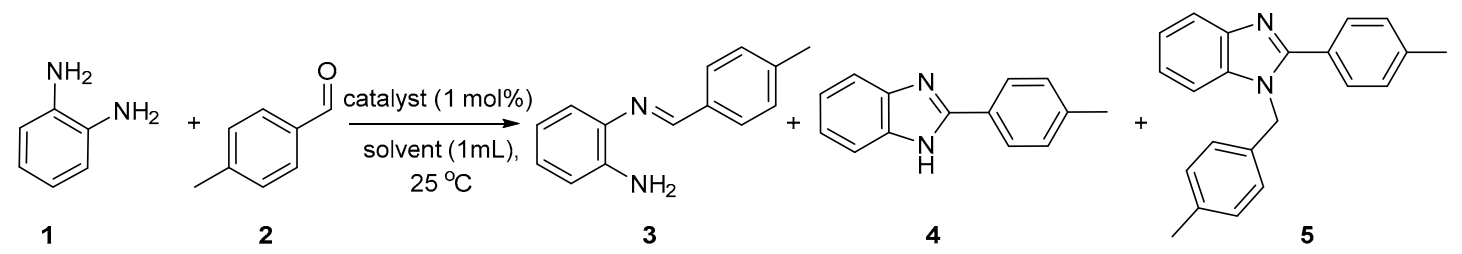

5

\begin{tabular}{|c|c|c|c|c|c|c|c|}
\hline Entry & Catalyst $^{a}$ & Solvent & Time (h) & $2(\%)^{b}$ & $3(\%)^{b}$ & $4(\%)^{b}$ & $5(\%)^{b}$ \\
\hline 1 & $\mathrm{Au} / \mathrm{ZnO}$ & $\mathrm{MeOH}$ & 18 & 27 & - & 73 & - \\
\hline 2 & $\mathrm{Au} / \mathrm{Al}_{2} \mathrm{O}_{3}$ & $\mathrm{MeOH}$ & 18 & 19 & - & 81 & - \\
\hline 3 & $\mathrm{Au} / \mathrm{TiO}_{2}$ & $\mathrm{MeOH}$ & 18 & 0 & - & 100 & - \\
\hline 4 & $\mathrm{Au} / \mathrm{Al}_{2} \mathrm{O}_{3}$ & $\mathrm{CH}_{3} \mathrm{CN}$ & 18 & 0 & 16 & 50 & 34 \\
\hline 5 & $\mathrm{Au} / \mathrm{TiO}_{2}$ & $\mathrm{CH}_{3} \mathrm{CN}$ & 18 & 0 & 57 & 43 & - \\
\hline 6 & $\mathrm{Au} / \mathrm{TiO}_{2}$ & 1,2-DCE & 18 & 0 & 82 & 18 & - \\
\hline 7 & $\mathrm{Au} / \mathrm{TiO}_{2}$ & EtOAc & 18 & 0 & 61 & 26 & 13 \\
\hline 8 & $\mathrm{Au} / \mathrm{TiO}_{2}$ & $\mathrm{THF}$ & 18 & 0 & 100 & - & - \\
\hline 9 & $\mathrm{Au} / \mathrm{TiO}_{2}$ & Toluene & 18 & 0 & 71 & 16 & 13 \\
\hline 10 & $\mathrm{Au} / \mathrm{TiO}_{2}$ & $\mathrm{EtOH}$ & 2 & 0 & 49 & 51 & - \\
\hline 11 & $\mathrm{Au} / \mathrm{TiO}_{2}$ & $\mathrm{MeOH}$ & 2 & 0 & 63 & 37 & - \\
\hline 12 & $\mathrm{Au} / \mathrm{TiO}_{2}$ & $\mathrm{CHCl}_{3}$ & 2 & 6 & - & 94 & - \\
\hline $13^{c}$ & $\mathrm{hv} / \mathrm{Au} / \mathrm{TiO}_{2}$ & $\mathrm{CH}_{3} \mathrm{CN}$ & 3 & 6 & 10 & 48 & 36 \\
\hline 14 & $\mathrm{Au} / \mathrm{TiO}_{2}$ & $\mathrm{CHCl}_{3}: \mathrm{MeOH}(3: 1)$ & 2 & 0 & - & 100 & - \\
\hline 15 & $\mathrm{Au} / \mathrm{Al}_{2} \mathrm{O}_{3}$ & $\mathrm{CHCl}_{3}: \mathrm{MeOH}(3: 1)$ & 2 & 0 & 25 & 75 & - \\
\hline 16 & $\mathrm{Au} / \mathrm{ZnO}$ & $\mathrm{CHCl}_{3}: \mathrm{MeOH}(3: 1)$ & 2 & 0 & 42 & 58 & - \\
\hline $17^{\mathrm{d}}$ & $\mathrm{Au} / \mathrm{TiO}_{2}(3 \mathrm{~mol} \%)$ & $\mathrm{CHCl}_{3}: \mathrm{MeOH}(3: 1)$ & 2 & 0 & - & 100 & - \\
\hline $18^{\mathrm{d}}$ & $\mathrm{Au} / \mathrm{MTA}(1)$ & $\mathrm{CHCl}_{3}: \mathrm{MeOH}(3: 1)$ & 2 & 0 & - & 91 & 9 \\
\hline $19^{d}$ & $\mathrm{Au} / \mathrm{MTA}(2)$ & $\mathrm{CHCl}_{3}: \mathrm{MeOH}(3: 1)$ & 2 & 0 & - & 85 & 15 \\
\hline $20^{d}$ & $\mathrm{Au} / \mathrm{MTA}(3)$ & $\mathrm{CHCl}_{3}: \mathrm{MeOH}(3: 1)$ & 2 & 0 & 17 & 54 & 29 \\
\hline $21^{d}$ & $\mathrm{Au} / \mathrm{MTA}(5)$ & $\mathrm{CHCl}_{3}: \mathrm{MeOH}(3: 1)$ & 2 & 0 & 30 & 44 & 26 \\
\hline
\end{tabular}

a Reaction conditions: $0.1 \mathrm{mmol}$ of $\mathbf{1}, 0.1 \mathrm{mmol}$ of 2 , catalyst $(1 \mathrm{~mol} \%), 1 \mathrm{~mL}$ of solvent, at $25^{\circ} \mathrm{C}$. The commercially available catalysts $\mathrm{Au} / \mathrm{TiO}_{2}, \mathrm{Au} / \mathrm{Al}_{2} \mathrm{O}_{3}$, and $\mathrm{Au} / \mathrm{ZnO}$ feature a ca. 1 wt.\% Au loading and exhibit an average AuNP size of about $2-3 \mathrm{~nm}$. ${ }^{\mathrm{b}}$ Yields of 2,3,4, and 5 were determined by ${ }^{1} \mathrm{H}$ NMR from the crude reaction mixture. ${ }^{c}$ Reaction conditions: $1(0.1 \mathrm{mmol}), 2(0.1 \mathrm{mmol}), \mathrm{Au} / \mathrm{TiO}_{2}(20 \mathrm{mg})$, solvent $(1 \mathrm{~mL})$ at white LEDs for $3 \mathrm{~h}$. ${ }^{\mathrm{d}}$ The amount of $60 \mathrm{mg}$ from $\mathrm{Au} / \mathrm{TiO}_{2}$ were used. e The catalysts Au/MTA(1), Au/MTA(2), Au/MTA(3), and Au/MTA(5) contain nanoparticles with diameters of $4.4,5.2,7.1$, and $9.4 \mathrm{~nm}$, respectively, and were used in $1 \mathrm{~mol} \%$ based on the 2 amount. 


\subsection{Synthesis of 2-Aryl and 2-Alkyl Benzimidazoles Catalyzed by Gold Nanoparticles}

With these optimized conditions, we further explored the scope of this catalytic transformation by incorporating a wide range of commercially available aromatic aldehydes to gain direct access to a library of 2-aryl substituted benzimidazole derivatives in high isolated yields (Scheme 3). For the present heterogeneous conditions, $\mathrm{Au} / \mathrm{TiO}_{2}(60 \mathrm{mg}, 1 \mathrm{wt} . \%$ or $0.003 \mathrm{mmol} \mathrm{Au})$ was used as the selected catalyst for testing this optimization, as well as $0.3 \mathrm{mmol}$ of the starting aldehyde and $0.3 \mathrm{mmol}$ of the amine 1 were used. Regardless of the electronic nature of the phenyl rings of the aromatic aldehydes, bearing even electron-donating $\left(\mathrm{Me}, \mathrm{OMe}, \mathrm{OH}, \mathrm{OAc}, \mathrm{NH}_{2}, \mathrm{Ph}\right.$ ) or electron-withdrawing $\left(\mathrm{Cl}, \mathrm{Br}, \mathrm{COOMe}, \mathrm{COOH}, \mathrm{CN}, \mathrm{NO}_{2}\right)$ groups, at $o-, m$ - or $p$ - position, the desired 2-aryl substituted benzimidazoles $(\mathbf{4}, \mathbf{6}-\mathbf{2 5})$ were formed in good to high isolated yields, ranging from $51 \%$ to $99 \%$ (Scheme 3). In most cases, the desired product was isolated by centrifuging of the crude reaction mixture to separate the solid catalyst from the synthesized 2-aryl benzimidazole. However, in some cases, the product was further purified using a column chromatographic with silica gel and the appropriate mixture of EtOAc/DCM as the eluent (see Supplementary Materials). To expand the application of the present synthetic methodology, 1-naphthaldehyde and heterocyclic aromatic aldehydes, such as the 2-furaldehyde, the 5-(hydroxymethyl)-2-furaldehyde, and the 5-bromo-2-furaldehyde, as well as the thiophene-2-carbaldehyde, give the corresponding products, 26-30, in high yields $(80-96 \%)$ as shown in Scheme 3. Moreover, the reaction between $o$-phenylenediamine and 6-isopropyl-4-oxo- $4 \mathrm{H}$-chromene-3-carbaldehyde was performed, and the corresponding substituted benzimidazole 31 was formed in high isolated yield (96\%) (Scheme 3). It is worth noting that all the reactions above were also accomplished in the absence of $\mathrm{Au} / \mathrm{TiO}_{2}$ and under the same conditions. In all cases, mixture of the corresponding imines, the 1,2-disubstituted benzimidazole derivatives, and the desired 2-aryl substituted imidazoles, was observed by ${ }^{1} \mathrm{H}$ NMR, without worth-mentioning good selectivity towards the later. These observations support further the importance of the present heterogeneous catalytic system for the synthesis of such $N$-heterocyclic compounds.

With the optimizing conditions in hand, we continued with the synthesis of several 2-alkyl-benzimidazoles, starting with the corresponding aliphatic aldehydes and the diamine $\mathbf{1}$. The products 32-39 were formed and isolated in 80-98\% yields, and the results are summarized in Scheme 4. It is interesting that under the present catalytic methodology, unstable aldehydes such as trans-2-phenylcyclopropyl aldehyde and cinnamaldehyde react smoothly, forming the corresponding 2-substituted benzimidazoles 34 and 32, respectively, in high yields of 88 and 96\% (Scheme 4).

These results indicate the broad generality of the present catalytic heterogeneous methodology toward the selective synthesis of 2-aryl and 2-alkyl substituted benzimidazoles. The structures of the products were determined by ${ }^{1} \mathrm{H}$ and ${ }^{13} \mathrm{C}$ NMR and HRMS (see Supplementary Materials). Exceptions to the generality of the above gold-catalyzed synthetic methodology constitute the reactions of 2-nitrobenzaldehyde $\mathbf{4 0}$ and the 6-nitro-4-oxo- $4 \mathrm{H}$-chromene-3-carbaldehyde $\mathbf{4 2}$ with the diamine $\mathbf{1}$, where the formation of the corresponding imine intermediate $\mathbf{4 1}$ and the precipitation of an unidentified solid residue were observed, respectively (Scheme 5). Consequently, a laboratory-scale procedure was also performed for the direct synthesis of 4 starting from $1 \mathrm{mmol}$ of $o$-phenylenediamine (1) and $1 \mathrm{mmol}$ of 4-methylbenzaldehyde (2) (Scheme 5). After the completion of the reaction (monitored by TLC), the slurry was centrifuged to separate the solid catalyst from the supernatant. The solid catalysts were washed three times with the aid of methanol ca. $5 \mathrm{~mL}$. The organic layers were collected, and the solvent mixture was evaporated under a vacuum to afford the corresponding product 4 in $96 \%$ yield after simple recrystallization over methanol. Based on the present heterogeneous protocol, we also proceeded to the synthesis of the structurally regio-isomer of the antifungal and antiparasitic Thiabendazole, compound $\mathbf{4 4}$, with one-step manner, starting simply from the commercially available aldehyde $\mathbf{4 3}$ and diamine $\mathbf{1}$ (Scheme 5) [84-86]. It is interesting that at $25^{\circ} \mathrm{C}$, the only observed product was the corresponding imine in $>99 \%$ yield. Thus, increasing gradually the reaction temperature to $50{ }^{\circ} \mathrm{C}$ and after $18 \mathrm{~h}$, the desired product 44 was observed, purified with column chromatography, 
and isolated in $92 \%$ yield $\left(55 \mathrm{mg}\right.$ ) with no byproduct's formation based on ${ }^{1} \mathrm{H}$ NMR analysis. Based on these results, the present one-pot process supports unambiguously the synthetic importance of the proposed catalytic methodology. Previously reported synthetic approaches towards Thiabendazole required external acid additives, harsh reaction conditions, and high temperatures $[87,88]$.
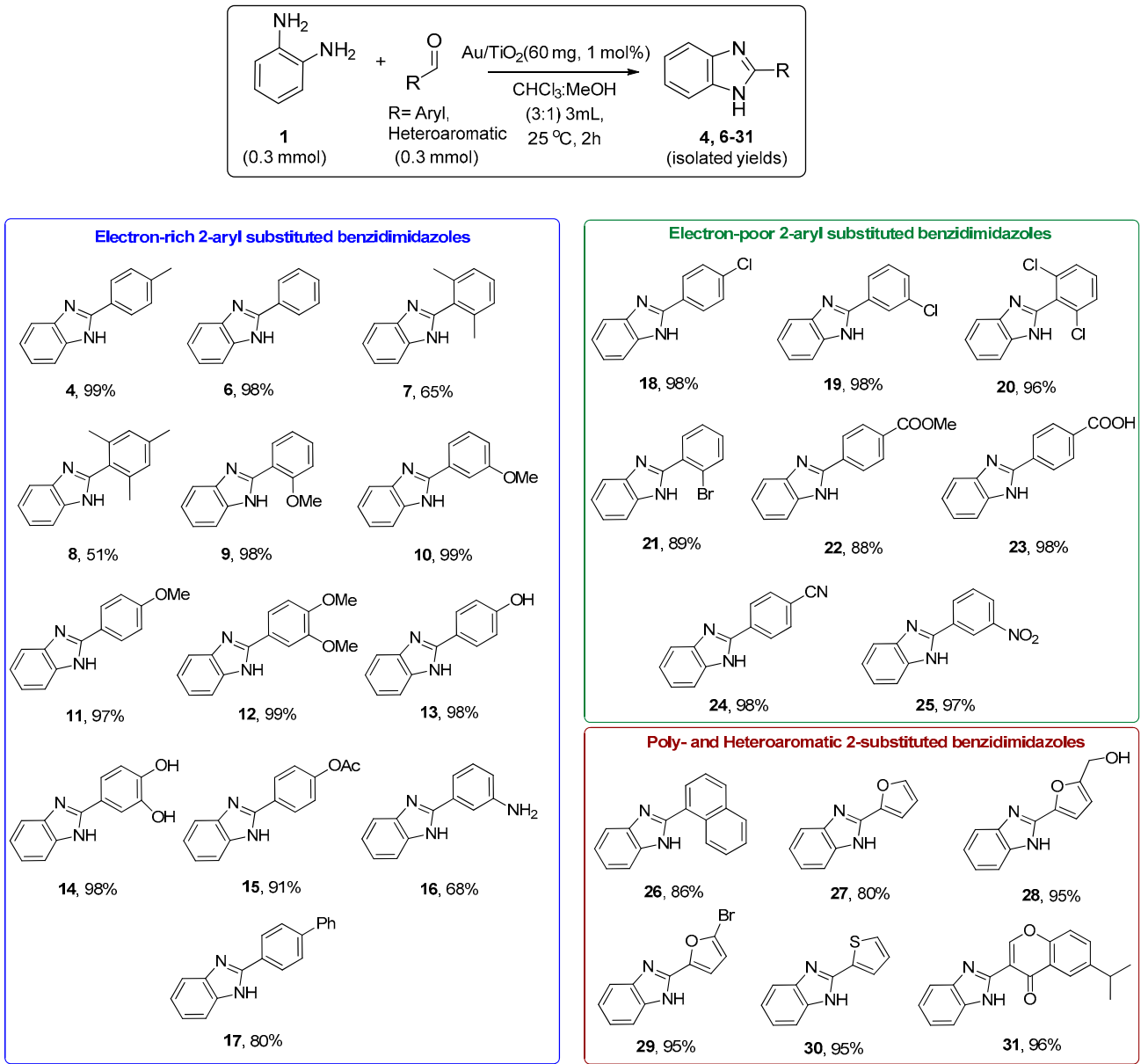

Scheme 3. Synthesis of 2-aryl substituted benzimidazoles 4, 6-31 in the presence of $\mathrm{Au} / \mathrm{TiO}_{2}$.
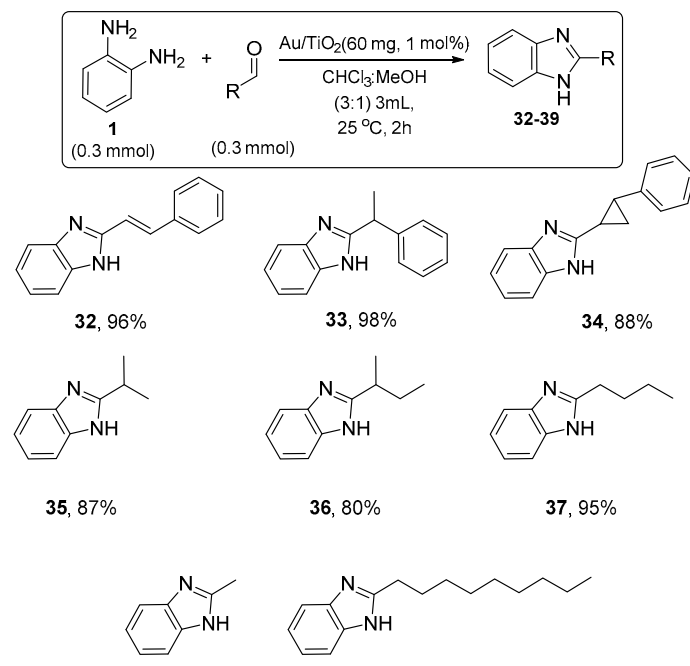

$38,98 \% \quad 39,95 \%$

Scheme 4. Synthesis of 2-alkyl substituted benzimidazoles 32-39 in the presence of $\mathrm{Au} / \mathrm{TiO}_{2}$. 

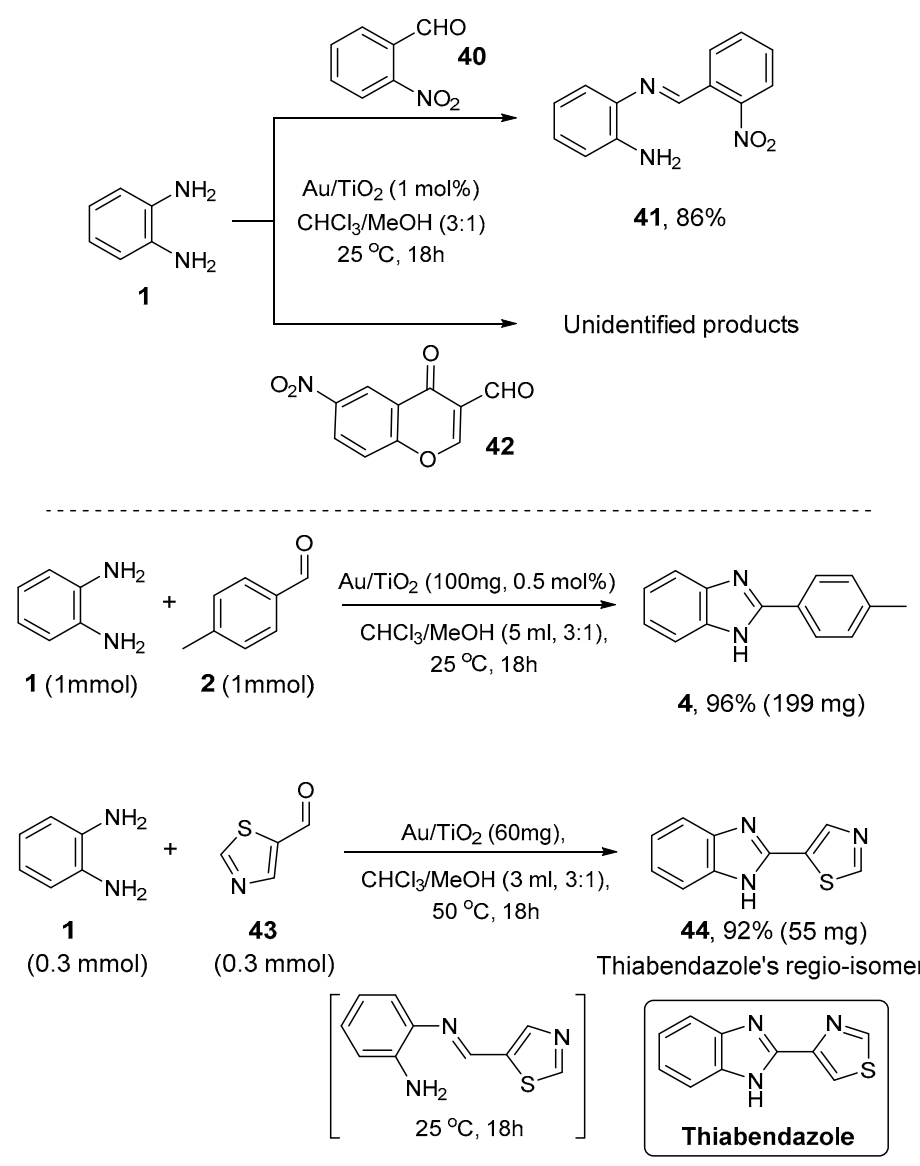

Scheme 5. Structure limitation, lab-scale synthesis of $\mathbf{4}$, and thiabendazole regio-isomer $\mathbf{4 4}$ over $\mathrm{Au} / \mathrm{TiO}_{2}$.

\subsection{Recycling and Mechanistic Studies}

Because of the heterogenicity of the present catalytic system, $\mathrm{Au} / \mathrm{TiO} \mathrm{O}_{2}$ can be easily separated from the reaction mixture with a simple centrifuge and the solid catalyst can be washed and reused for the next run. Based on this feature, the recyclability and stability of this material were examined, studying the synthesis of 4 on the above described conditions. In details, $0.2 \mathrm{mmol}$ of 1 and $0.2 \mathrm{mmol}$ of 2 were reacted in the presence of $40 \mathrm{mg}$ of $\mathrm{Au} / \mathrm{TiO}_{2}(1 \% w / w)$ at $1.5 \mathrm{~mL}$ of $\mathrm{CHCl}_{3}: \mathrm{MeOH}(3: 1)$ and at $25^{\circ} \mathrm{C}$. After the reaction completion within $2 \mathrm{~h}$ (monitored by TLC), the slurry was centrifuged to separate the solid catalyst from the supernatant. The solid catalysts were washed three times with the aid of methanol ca. $3 \mathrm{~mL}$ and the organic supernatants were collected, and the solvent mixture was evaporated under vacuum to afford the corresponding product 4 . The solid material was dried within the oven at $100{ }^{\circ} \mathrm{C}$ overnight and reused for the next catalytic run without any further purification. In Figure 2, the reaction profile based on 4 yield vs. reaction run was presented. As it was shown, the catalyst can be used at least five times without significant loss of its activity towards the synthesis of 4. This observation is in agreement with previous work on the selective synthesis of benzoxazoles and 2-aryl benzimidazoles, starting with benzyl alcohols and 2-nitroaniline, in toluene and at $150{ }^{\circ} \mathrm{C}$, using $\mathrm{Au} / \mathrm{TiO}_{2}$ as the catalyst [70]. Additionally, to support the necessity of the AuNPs, as well as to indicate possible leaching of the AuNPs into the reaction mixture, a slurry of $20 \mathrm{mg}$ of $\mathrm{Au} / \mathrm{TiO}_{2}$ $(1 \% w / w)$ in $1 \mathrm{~mL}$ of $\mathrm{CHCl}_{3}: \mathrm{MeOH}=3: 1$ was stirred for $2 \mathrm{~h}$. Then, the supernatant solution was found to be inefficient to promote the selective synthesis of the desired 4 ; however, a mixture of 3, 4, and 5 was observed by ${ }^{1} \mathrm{H}$ NMR, in $22 \%, 31 \%$, and $47 \%$ yields, respectively; similar values to those measured in the corresponding experiment in the absence of a catalyst (Table 1, entry 19). This experiment supports 
the necessity of the supported AuNPs and implies that Au leaching into the solution is essentially minimal, if any.
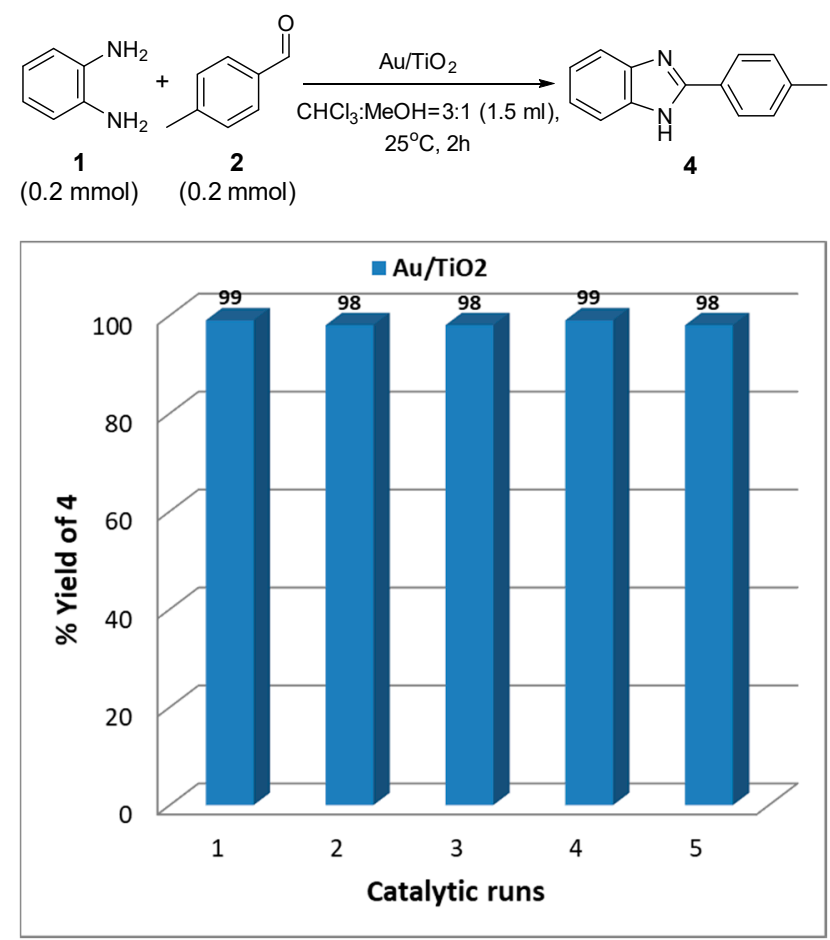

Figure 2. Catalytic runs using the $\mathrm{Au} / \mathrm{TiO}_{2}$ catalyst. Experimental conditions: $40 \mathrm{mg}$ of the catalyst, $0.2 \mathrm{mmol}$ of $\mathbf{1}, 0.2 \mathrm{mmol}$ of $2,1.5 \mathrm{~mL}$ of $\mathrm{CHCl}_{3}: \mathrm{MeOH}(3: 1), 25^{\circ} \mathrm{C}, \mathrm{t}=2 \mathrm{~h}$.

Supported AuNPs have been reported as excellent catalysts in cyclo-isomerization processes [64-67], via the proposed activation of unsaturated bonds [89,90] on the low coordinated electrophilic $\mathrm{Au}(0)$ atoms at the corners and edges of nanoparticles [83]. Based on this catalytic process and the present experimental results, a plausible mechanism for the synthesis of the benzimidazole derivatives can be proposed (Scheme 6). At the initial step, the aldehyde and the $o$-phenylenediamine react to generate the imine, which, in the present of the supported gold nanoparticles, led to the intermediate I via a cyclization process. This intermediate could undergo protodeauration, which releases the 2-susbtituted-2,3-dihydro- $1 H$-benzimidazole intermediate II from the chemisorbed species I. Then, after dehydrogenation, the corresponding benzimidazole product was formed, also regenerating the catalyst (Scheme 6). We did not detect intermediate II by NMR at any stage of the reaction. This notion implies that the dehydrogenation of II into benzimidazole occurs faster than the initial cyclization. A similar pathway is proposed in the literature on the synthesis of benzoxazoles and benzimidazoles catalyzed by $\mathrm{Au} / \mathrm{TiO}_{2}$ [70]. However, an alternative pathway, with the chemisorbed species I being transformed, via a dehydrogenation process, into the intermediate III, and after protodeauration to the benzimidazole, could also take place. Relevant dehydrogenation pathways are also proposed in the AuNP-catalyzed transformation of 1,2-dihydroquinolines to the corresponding quinolones [91], as well as in the synthesis of pyridines from the in situ generated N-propargyl enaminones [92]. Herein, partial charges were used for the intermediates I and III, based on previous calculations on the bonding nature of chemisorbed intermediates on Au clusters [93,94]. 


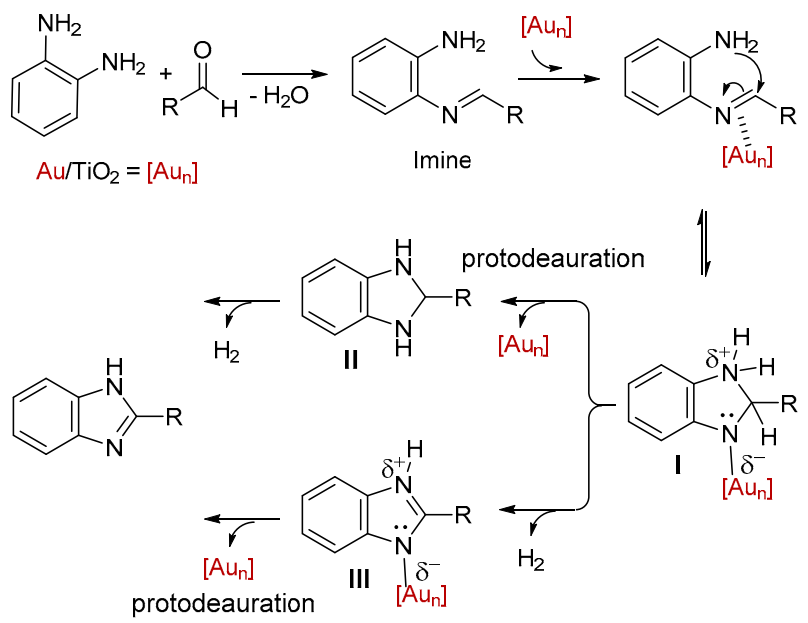

Scheme 6. Proposed mechanism of the $\mathrm{Au} / \mathrm{TiO}_{2}$-catalyzed oxidative cyclization of $o$-phenylenediamine with aldehyde.

\section{Conclusions}

In conclusion, the commercially available $\mathrm{Au} / \mathrm{TiO}_{2}$ ( $2-3 \mathrm{~nm}$ AuNPs size) was used as an efficient catalyst for the selective synthesis of 2-aryl and 2-alkyl substituted benzimidazoles. The present heterogeneous catalytic protocol includes the one-step reaction between the corresponding aldehyde and the o-phenylenediamine, at ambient conditions, and in $\mathrm{CHCl}_{3}: \mathrm{MeOH}(3: 1)$. This reaction has a broad substrate scope and represents a new heterogeneous methodology for practical C-N bond formation under mild conditions, without additional additives and oxidants. The small-size gold nanoparticles $(<5 \mathrm{~nm})$ supported on $\mathrm{TiO}_{2}$ were found to be the most active species under the present catalytic conditions. The catalyst $\mathrm{Au} / \mathrm{TiO}_{2}$ could be used at least five times without any significant loss of its catalytic efficacy. The present protocol applied to the lab-scale synthesis of 4-tolylbenzimidazole, as well as to the synthesis of the regio-isomer of the antifungal and antiparasitic Thiabendazole.

Supplementary Materials: The following are available online at http://www.mdpi.com/2079-4991/10/12/2405/s1. Scheme S1: Synthesis of benzimidazoles using metal oxides as heterogeneous catalysts, Scheme S2: Synthesis of benzimidazoles under photocatalytic reactions, Table S1. Homogeneous catalyst screening for the reaction between 1 and 2, Table S2: Heterogeneous surfaces screening for the reaction between 1 and 2, Table S3: Solvent screening for the reaction between 1 and 2 catalyzed by $\mathrm{Au} / \mathrm{Al}_{2} \mathrm{O}_{3},{ }^{1} \mathrm{H}$ and ${ }^{13} \mathrm{C} \mathrm{NMR}$ data and spectra of 2-substituted- $1 H$-1,3- benzodiazoles.

Author Contributions: Conceptualization, M.A.T. and I.N.L.; experimental methodology, catalytic study, and products analysis, M.A.T.; HRMS experiments C.G.; supervision, I.N.L. All authors have read and agreed to the published version of the manuscript.

Funding: This research was funded by the Hellenic Foundation for Research and Innovation (HFRI) and the General Secretariat for Research and Technology (GSRT) under Grant Agreement No. [776] "PhotoDaLu" (KA97507).

Acknowledgments: We thank G. E. Kostakis (School of Life Sciences, University of Sussex, U.K., G.Kostakis@sussex.ac.uk) for valuable comments and discussion. We thank G. S. Armatas (Department of Materials Science and Technology, UoC, garmatas@materials.uoc.gr) for the support and synthesis of the gold catalysts Au/MTA $(1,2,3$, and 5\% wt.) used in the present study. We thank D. A. Sarigiannis (sarigiannis@cheng.auth.gr) of the HERACLES Research Center, KEDEK, Laboratory of Environmental Engineering (EnvE-Lab), Department of Chemical Engineering, AUTH, Greece for using the LC-TOF apparatus and performing the HRMS experiments. The authors would like to acknowledge the Center of Interdisciplinary Research and Innovation of Aristotle University of Thessaloniki (CIRI-AUTH), Greece, for access to the Large Research Infrastructure and Instrumentation of the Nuclear Magnetic Resonance Laboratory at the Center for Research of the Structure of Matter in the Chemical Engineering Department, and especially we thank S. Matsia from the Laboratory of Inorganic Chemistry and Advanced Materials, Department of Chemical Engineering, AUTH, for performing the NMR experiments. I.N.L. also acknowledges the Empirikeion Foundation for the financial support of photo-reagents.

Conflicts of Interest: The authors declare no conflict of interest. 


\section{References}

1. Boiani, M.; Gonzalez, M. Imidazole and benzimidazole derivatives as chemotherapeutic agents. Mini-Rev. Med. Chem. 2005, 5, 409-424. [CrossRef]

2. Narasimhan, B.; Sharma, D.; Kumar, P. Benzimidazole: A medicinally important heterocyclic moiety. Med. Chem. Res. 2012, 21, 269-283. [CrossRef]

3. Bansal, Y.; Silakari, O. The therapeutic journey of benzimidazoles: A review. Bioorg. Med. Chem. 2012, 20, 6208-6236. [CrossRef] [PubMed]

4. Shah, K.; Chhabra, S.; Shrivastava, S.K.; Mishra, P. Benzimidazole: A promising pharmacophore. Med. Chem. Res. 2013, 22, 5077-5104. [CrossRef]

5. Yadav, G.; Ganguly, S. Structure activity relationship (SAR) study of benzimidazole scaffold for different biological activities: A mini-review. Eur. J. Med. Chem. 2015, 97, 419-443. [CrossRef] [PubMed]

6. Gaba, M.; Mohan, C. Development of drugs based on imidazole and benzimidazole bioactive heterocycles: Recent advances and future directions. Med. Chem. Res. 2016, 25, 173-210. [CrossRef]

7. Kazimierczuk, Z.; Upcroft, J.A.; Upcroft, P.; Górska, A.; Starościak, B.; Laudy, A. Synthesis, antiprotozoal and antibacterial activity of nitro- and halogeno-substituted benzimidazole derivatives. Acta Biochim. Pol. 2002, 49, 185-195. [CrossRef] [PubMed]

8. Ansari, K.F.; Lal, C. Synthesis and evaluation of some new benzimidazole derivatives as potential antimicrobial agents. Eur. J. Med. Chem. 2009, 44, 2294-2299. [CrossRef]

9. Ansari, K.F.; Lal, C. Synthesis, physicochemical properties and antimicrobial activity of some new benzimidazole derivatives. Eur. J. Med. Chem. 2009, 44, 4028-4033. [CrossRef]

10. Starčević, K.; Kralj, M.; Ester, K.; Sabol, I.; Grce, M.; Pavelić, K.; Karminski-Zamola, G. Synthesis, antiviral and antitumor activity of 2-substituted-5-amidino-benzimidazoles. Bioorg. Med. Chem. 2007, 15, 4419-4426. [CrossRef]

11. Gellis, A.; Kovacic, H.; Boufatah, N.; Vanelle, P. Synthesis and cytotoxicity evaluation of some benzimidazole-4,7-diones as bioreductive anticancer agents. Eur. J. Med. Chem. 2008, 43, 1858-1864. [CrossRef] [PubMed]

12. Purushottamachar, P.; Ramalingam, S.; Njar, V.C. Development of benzimidazole compounds for cancer therapy. In Chemistry and Applications of Benzimidazole and Its Derivatives; Marinescu, M., Ed.; IntechOpen: Rijeka, Croatia, 2019; ISBN 978-1-78984-552-5.

13. Hranjec, M.; Starčević, K.; Pavelić, S.K.; Lučin, P.; Pavelić, K.; Karminski Zamola, G. Synthesis, spectroscopic characterization and antiproliferative evaluation in vitro of novel Schiff bases related to benzimidazoles. Eur. J. Med. Chem. 2011, 46, 2274-2279. [CrossRef] [PubMed]

14. Shrivastava, N.; Naim, M.J.; Alam, M.J.; Nawaz, F.; Ahmed, S.; Alam, O. Benzimidazole scaffold as anticancer agent: Synthetic approaches and structure-activity relationship: Benzimidazole Scaffold as Anticancer Agent. Arch. Pharm. Chem. Life Sci. 2017, 350, e201700040. [CrossRef] [PubMed]

15. Labanauskas, L.K.; Brukštus, A.B.; Gaidelis, P.G.; Buchinskaite, V.A.; Udrenaite, É.B.; Daukšas, V.K. Synthesis and antiinflammatory activity of some new 1-acyl derivatives of 2-methylthio-5,6-diethoxybenzimidazole. Pharm. Chem. J. 2000, 34, 353-355. [CrossRef]

16. Tsukamoto, G.; Yoshino, K.; Kohno, T.; Ohtaka, H.; Kagaya, H.; Ito, K. 2-Substituted azole derivatives. 1. Synthesis and antiinflammatory activity of some 2-(substituted-pyridinyl)benzimidazoles. J. Med. Chem. 1980, 23, 734-738. [CrossRef] [PubMed]

17. Ito, K.; Kagaya, H.; Fukuda, T.; Yoshino, K.; Nose, T. Pharmacological studies of a new non-steroidal antiinflammatory drug: 2-(5-ethylpyridin-2-yl)benzimidazole (KB-1043). Arzneimittelforschung 1982, 32, 49-55. [PubMed]

18. Can-Eke, B.; Orhan Puskullu, M.; Buyukbingol, E.; Iscan, M. A study on the antioxidant capacities of some benzimidazoles in rat tissues. Chem. Biol. Interact. 1998, 113, 65-77. [CrossRef]

19. Powell, D.A.; Ramtohul, Y.; Lebrun, M.-E.; Oballa, R.; Bhat, S.; Falgueyret, J.-P.; Guiral, S.; Huang, Z.; Skorey, K.; Tawa, P.; et al. 2-Aryl benzimidazoles: Human SCD1-specific stearoyl coenzyme-A desaturase inhibitors. Bioorg. Med. Chem. Lett. 2010, 20, 6366-6369. [CrossRef]

20. Shingalapur, R.V.; Hosamani, K.M.; Keri, R.S.; Hugar, M.H. Derivatives of benzimidazole pharmacophore: Synthesis, anticonvulsant, antidiabetic and DNA cleavage studies. Eur. J. Med. Chem. 2010, 45, 1753-1759. [CrossRef] 
21. Ishikawa, M.; Nonoshita, K.; Ogino, Y.; Nagae, Y.; Tsukahara, D.; Hosaka, H.; Maruki, H.; Ohyama, S.; Yoshimoto, R.; Sasaki, K.; et al. Discovery of novel 2-(pyridine-2-yl)-1H-benzimidazole derivatives as potent glucokinase activators. Bioorg. Med. Chem. Lett. 2009, 19, 4450-4454. [CrossRef]

22. Wright, J.B. The chemistry of the benzimidazoles. Chem. Rev. 1951, 48, 397-541. [CrossRef] [PubMed]

23. Preston, P.N. Synthesis, reactions, and spectroscopic properties of benzimidazoles. Chem. Rev. 1974, 74, 279-314. [CrossRef]

24. Alaqeel, S.I. Synthetic approaches to benzimidazoles from o-phenylenediamine: A literature review. J. Saudi Chem. Soc. 2017, 21, 229-237. [CrossRef]

25. Panda, S.; Malik, R.; Jain, C.S. Synthetic approaches to 2-arylbenzimidazoles: A review. Curr. Org. Chem. 2012, 16, 1905-1919. [CrossRef]

26. Bahrami, K.; Khodaei, M.M.; Naali, F. Mild and Highly Efficient Method for the Synthesis of 2-arylbenzimidazoles and 2-arylbenzothiazoles. J. Org. Chem. 2008, 73, 6835-6837. [CrossRef]

27. Karami, C.; Ghodrati, K.; Izadi, M.; Farrokh, A.; Jafari, S.; Mahmoudiyani, M.; Haghnazari, N. A Fast procedure for the preparation of benzimidazole derivatives using polymer-supported with trifluoromethanesulfonic acid as novel and reusable catalyst. J. Chil. Chem. Soc. 2013, 58, 1914-1917. [CrossRef]

28. Zhu, C.; Wei, Y. An inorganic iodine-catalyzed oxidative system for the synthesis of benzimidazoles using hydrogen peroxide under ambient conditions. ChemSusChem 2011, 4, 1082-1086. [CrossRef]

29. Du, L.-H.; Wang, Y.-G. A Rapid and efficient synthesis of benzimidazoles using hypervalent iodine as oxidant. Synthesis 2007, 2007, 675-678. [CrossRef]

30. Bellina, F.; Cauteruccio, S.; Rossi, R. Palladium- and copper-mediated direct C-2 arylation of azoles-Including free $(\mathrm{NH})$-imidazole, -benzimidazole and -indole-Under base-free and ligandless conditions. Eur. J. Org. Chem. 2006, 2006, 1379-1382. [CrossRef]

31. Cimarelli, C.; Di Nicola, M.; Diomedi, S.; Giovannini, R.; Hamprecht, D.; Properzi, R.; Sorana, F.; Marcantoni, E. An efficient one-pot two catalyst system in the construction of 2-substituted benzimidazoles: Synthesis of benzimidazo[1,2-c]quinazolines. Org. Biomol. Chem. 2015, 13, 11687-11695. [CrossRef]

32. Soleimani, E.; Khodaei, M.M.; Yazdani, H.; Saei, P.; Zavar Reza, J. Synthesis of 2-substituted benzimidazoles and benzothiazoles using $\mathrm{Ag}_{2} \mathrm{CO}_{3} /$ Celite as an efficient solid catalyst. J. Iran. Chem. Soc. 2015, 12, 1281-1285. [CrossRef]

33. Trivedi, R.; De, S.K.; Gibbs, R.A. A convenient one-pot synthesis of 2-substituted benzimidazoles. J. Mol. Catal. A Chem. 2006, 245, 8-11. [CrossRef]

34. Curini, M.; Epifano, F.; Montanari, F.; Rosati, O.; Taccone, S. Ytterbium triflate promoted synthesis of benzimidazole derivatives. Synlett 2004, 1832-1834. [CrossRef]

35. Hegedüs, A.; Hell, Z.; Potor, A. Zeolite-catalyzed environmentally friendly synthesis of benzimidazole derivatives. Synth. Commun. 2006, 36, 3625-3630. [CrossRef]

36. Mobinikhaledi, A.; Forughifar, N.; Zendehdel, M.; Jabbarpour, M. Conversion of aldehydes to benzimidazoles using NaY zeolite. Synth. React. Inorg. Met. Org. Nano-Met. Chem. 2008, 38, 390-393. [CrossRef]

37. Mobinikhaledi, A.; Zendehdel, M.; Goudarzi, F.; Bardajee, G.R. Nano-Ni(II)/Y Zeolite catalyzed synthesis of 2-aryl- and 2-alkyl benzimidazoles under solvent-free conditions. Synth. React. Inorg. Met. Org. Nano-Met. Chem. 2016, 46, 1526-1531. [CrossRef]

38. Nguyen, T.T.; Nguyen, X.-T.T.; Nguyen, T.-L.H.; Tran, P.H. Synthesis of benzoxazoles, benzimidazoles, and benzothiazoles using a Brønsted acidic ionic liquid gel as an efficient heterogeneous catalyst under a solvent-free condition. ACS Omega 2019, 4, 368-373. [CrossRef]

39. Bahrami, K.; Khodaei, M.M.; Nejati, A. Synthesis of 1,2-disubstituted benzimidazoles, 2-substituted benzimidazoles and 2-substituted benzothiazoles in SDS micelles. Green Chem. 2010, 12, 1237-1241. [CrossRef]

40. Adharvana Chari, M.; Shobha, D.; Sasaki, T. Room temperature synthesis of benzimidazole derivatives using reusable cobalt hydroxide (II) and cobalt oxide (II) as efficient solid catalysts. Tetrahedron Lett. 2011, 52, 5575-5580. [CrossRef]

41. Das, B.; Kanth, B.S.; Reddy, K.R.; Kumar, A.S. Sulfonic acid functionalized silica as an efficient heterogeneous recyclable catalyst for one-pot synthesis of 2-substituted benziimidazoles. J. Heterocycl. Chem. 2008, 45, 1499-1502. [CrossRef] 
42. Bahrami, K.; Bakhtiarian, M. Mesoporous titania-alumina mixed oxide: A heterogeneous nanocatalyst for the synthesis of 2-substituted benzimidazoles, benzothiazoles and benzoxazoles. ChemistrySelect 2018, 3, 10875-10880. [CrossRef]

43. Chen, B.; Zhang, C.; Niu, L.; Shi, X.; Zhang, H.; Lan, X.; Bai, G. Biomass-derived N-doped carbon materials with silica-supported ultrasmall $\mathrm{ZnO}$ nanoparticles: Robust catalysts for the Green synthesis of benzimidazoles. Chem. Eur. J. 2018, 24, 3481-3487. [CrossRef] [PubMed]

44. Bandyopadhyay, P.; Sathe, M.; Ponmariappan, S.; Sharma, A.; Sharma, P.; Srivastava, A.K.; Kaushik, M.P. Exploration of in vitro time point quantitative evaluation of newly synthesized benzimidazole and benzothiazole derivatives as potential antibacterial agents. Bioorg. Med. Chem. Lett. 2011, 21, 7306-7309. [CrossRef] [PubMed]

45. Fazaeli, R.; Aliyan, H. A Heterogeneous catalyst for efficient and green synthesis of 2-arylbenzothiazoles and 2-arylbenzimidazoles. Appl. Catal. A Gen. 2009, 353, 74-79. [CrossRef]

46. Samanta, P.K.; Banerjee, R.; Richards, R.M.; Biswas, P. Mesoporous silica supported ytterbium as catalyst for synthesis of 1,2-disubstituted benzimidazoles and 2-substituted benzimidazoles: Mesoporous silica supported ytterbium as heterogeneous catalyst. Appl. Organomet. Chem. 2018, 32, e4507. [CrossRef]

47. Shingalapur, R.V.; Hosamani, K.M. An efficient and eco-friendly tungstate promoted zirconia $\left(\mathrm{WO}_{\mathrm{x}} / \mathrm{ZrO}_{2}\right)$ solid acid catalyst for the synthesis of 2-aryl benzimidazoles. Catal. Lett. 2010, 137, 63-68. [CrossRef]

48. Sodhi, R.K.; Paul, S. Nanosized Mn(acac) $)_{3}$ anchored on amino functionalized silica for the selective oxidative synthesis of 2-arylbenzimidazoles, 2-arylbenzothiazoles and aerobic oxidation of benzoins in water. Catal. Lett. 2011, 141, 608-615. [CrossRef]

49. Zakeri, M.; Moghadam, M.; Mirkhani, V.; Tangestaninejad, S.; Mohammadpoor-Baltork, I.; Pahlevanneshan, Z Copper containing nanosilica thioalated dendritic material: A recyclable catalyst for synthesis of benzimidazoles and benzothiazoles. Appl. Organomet. Chem. 2018, 32, e3937. [CrossRef]

50. Wade, A.R.; Pawar, H.R.; Biware, M.V.; Chikate, R.C. Synergism in semiconducting nanocomposites: Visible light photocatalysis towards the formation of C-S and C-N bonds. Green Chem. 2015, 17, 3879-3888. [CrossRef]

51. Samanta, S.; Das, S.; Biswas, P. Photocatalysis by 3,6-disubstituted-S-tetrazine: Visible-light driven metal-free green synthesis of 2-substituted benzimidazole and benzothiazole. J. Org. Chem. 2013, 78, 11184-11193. [CrossRef]

52. Kovvuri, J.; Nagaraju, B.; Kamal, A.; Srivastava, A.K. An efficient synthesis of 2-substituted benzimidazoles via photocatalytic condensation of $o$-phenylenediamines and aldehydes. ACS Comb. Sci. 2016, 18, 644-650. [CrossRef] [PubMed]

53. Park, S.; Jung, J.; Cho, E.J. Visible-light-promoted synthesis of benzimidazoles. Eur. J. Org. Chem. 2014, 2014, 4148-4154. [CrossRef]

54. Shiraishi, Y.; Sugano, Y.; Tanaka, S.; Hirai, T. One-pot synthesis of benzimidazoles by simultaneous photocatalytic and catalytic reactions on $\mathrm{Pt}_{\mathrm{TiO}}$ nanoparticles. Angew. Chem. Int. Ed. 2010, 122, 1700-1704. [CrossRef]

55. Eskandari, A.; Jafarpour, M.; Rezaeifard, A.; Salimi, M. A dendritic $\mathrm{TiO}_{2}-\mathrm{Co}$ (II) nanocomposite based on the melamine catalyzed one-pot aerobic photocatalytic synthesis of benzimidazoles. New J. Chem. 2018, 42, 6449-6456. [CrossRef]

56. Feizpour, F.; Jafarpour, M.; Rezaeifard, A. A tandem aerobic photocatalytic synthesis of benzimidazoles by cobalt ascorbic acid complex coated on $\mathrm{TiO}_{2}$ nanoparticles under visible light. Catal. Lett. 2018, 148, 30-40. [CrossRef]

57. Astruc, D. Transition-metal nanoparticles in catalysis: From historical background to the state-of-the art. In Nanoparticles and Catalysis; Astruc, D., Ed.; Wiley-VCH Verlag GmbH and Company KGaA: Weinheim, Germany, 2008; pp. 1-48.

58. Schmid, G. Clusters and Colloids. From Theory to Applications; Wiley-VCH: Weinheim, Germany, 2008.

59. Schmid, G. (Ed.) Nanoparticles. From Theory to Application; Wiley-VCH: Weinheim, Germany, 2010.

60. Sreeprasad, T.S.; Pradeep, T. Noble metal nanoparticles. In Springer Handbook of Nanomaterials; Vajtai, R., Ed.; Springer: Berlin, Germany, 2013; pp. 303-388.

61. Takale, B.S.; Bao, M.; Yamamoto, Y. Gold nanoparticle (AuNPs) and gold nanopore (AuNPore) catalysts in organic synthesis. Org. Biomol. Chem. 2014, 12, 2005-2027. [CrossRef] 
62. Bagheri, S.; Muhd Julkapli, N.; Bee Abd Hamid, S. Titanium dioxide as a catalyst support in heterogeneous catalysis. Sci. World J. 2014, 2014. [CrossRef]

63. Ma, Z.; Dai, S. Development of novel supported gold catalysts: A materials perspective. Nano Res. 2011, 4, 3-32. [CrossRef]

64. Corma, A.; Garcia, H. Supported gold nanoparticles as catalysts for organic reactions. Chem. Soc. Rev. 2008, 37, 2096-2126. [CrossRef]

65. Mielby, J.; Kegnaes, S.; Fristrup, P. Gold nanoparticle-catalyzed formation of nitrogen-containing compounds-from mechanistic understanding to synthetic exploitation. Chem CatChem 2012, 4, 1037-1047. [CrossRef]

66. Liu, X.; He, L.; Liu, Y.-M.; Cao, Y. Supported gold catalysis: From small molecule activation to green chemical synthesis. Acc. Chem. Res. 2014, 47, 793-804. [CrossRef] [PubMed]

67. Stratakis, M.; Lykakis, I.N. Nanogold(0)-catalyzed addition of heteroelement $\sigma$ linkages to functional groups. Synthesis 2019, 51, 2435-2454. [CrossRef]

68. Ruiz, V.R.; Corma, A.; Sabater, M.J. New route for the synthesis of benzimidazoles by a one-pot multistep process with mono and bifunctional solid catalysts. Tetrahedron 2010, 66, 730-735. [CrossRef]

69. Climent, M.J.; Corma, A.; Iborra, S.; Martínez-Silvestre, S. Gold catalysis opens up a new route for the synthesis of benzimidazoylquinoxaline derivatives from biomass-derived products (Glycerol). ChemCatChem 2013, 5, 3866-3874. [CrossRef]

70. Tang, L.; Guo, X.; Yang, Y.; Zha, Z.; Wang, Z. Gold nanoparticles supported on titanium dioxide: An efficient catalyst for highly selective synthesis of benzoxazoles and benzimidazoles. Chem. Commun. 2014, 50, 6145-6148. [CrossRef]

71. Didó, C.A.; Mass, E.B.; Pereira, M.B.; Hinrichs, R.; D’Oca, M.G.M.; Costa, T.M.H.; Russowsky, D.; Benvenutti, E.V. Heterogeneous gold nanocatalyst applied in the synthesis of 2-aryl-2,3-dihydroquinazolin-4(1H)-ones. Colloids Surf. A Physicochem. Eng. Asp. 2020, 589, 124455. [CrossRef]

72. Tzani, M.A.; Kallitsakis, M.G.; Symeonidis, T.S.; Lykakis, I.N. Alumina-supported gold nanoparticles as a bifunctional catalyst for the synthesis of 2-amino-3-arylimidazo[1,2-a]pyridines. ACS Omega 2018, 3, 17947-17956. [CrossRef]

73. Andreou, D.; Kallitsakis, M.G.; Loukopoulos, E.; Gabriel, C.; Kostakis, G.E.; Lykakis, I.N. Copper-promoted regioselective synthesis of polysubstituted pyrroles from aldehydes, amines, and nitroalkenes via 1,2-phenyl/alkyl migration. J. Org. Chem. 2018, 83, 2104-2113. [CrossRef]

74. Kallitsakis, M.; Loukopoulos, E.; Abdul-Sada, A.; Tizzard, G.J.; Coles, S.J.; Kostakis, G.E.; Lykakis, I.N. A copper-benzotriazole-based coordination polymer catalyzes the efficient one-pot synthesis of ( $N^{\prime}$-substituted)-hydrazo-4-aryl-1,4-dihydropyridines from azines. Adv. Synth. Catal. 2017, 359, 138-145. [CrossRef]

75. Charistoudi, E.; Kallitsakis, M.G.; Charisteidis, I.; Triantafyllidis, K.S.; Lykakis, I.N. Selective reduction of azines to benzyl hydrazones with sodium borohydride catalyzed by mesoporous silica-supported silver nanoparticles: A catalytic route towards pyrazole synthesis. Adv. Synth. Catal. 2017, 359, 2949-2960. [CrossRef]

76. Papadas, I.T.; Fountoulaki, S.; Lykakis, I.N.; Armatas, G.S. Controllable synthesis of mesoporous iron oxide nanoparticle assemblies for chemoselective catalytic reduction of nitroarenes. Chem. Eur. J. 2016, 22, 4600-4607. [CrossRef] [PubMed]

77. Fountoulaki, S.; Daikopoulou, V.; Gkizis, P.L.; Tamiolakis, I.; Armatas, G.S.; Lykakis, I.N. Mechanistic studies of the reduction of nitroarenes by $\mathrm{NaBH}_{4}$ or hydrosilanes catalyzed by supported gold nanoparticles. ACS Catal. 2014, 4, 3504-3511. [CrossRef]

78. Tamiolakis, I.; Fountoulaki, S.; Vordos, N.; Lykakis, I.N.; Armatas, G.S. Mesoporous Au-TiO 2 nanoparticle assemblies as efficient catalysts for the chemoselective reduction of nitro compounds. J. Mater. Chem. A 2013, 1, 14311-14319. [CrossRef]

79. Gkizis, P.L.; Stratakis, M.; Lykakis, I.N. Catalytic activation of hydrazine hydrate by gold nanoparticles: Chemoselective reduction of nitro compounds into amines. Catal. Commun. 2013, 36, 48-51. [CrossRef]

80. Fountoulaki, S.; Gkizis, P.L.; Symeonidis, T.S.; Kaminioti, E.; Karina, A.; Tamiolakis, I.; Armatas, G.S.; Lykakis, I.N. Titania-supported gold nanoparticles catalyze the selective oxidation of amines into nitroso compounds in the presence of hydrogen peroxide. Adv. Synth. Catal. 2016, 358, 1500-1508. [CrossRef] 
81. Elumalai, V.; Hansen, J.H. A green, scalable, one-minute synthesis of benzimidazoles. Synlett 2020, 31, 547-552. [CrossRef]

82. Maioli, M.; Varadi, G.; Kurdi, R.; Caglioti, L.; Palyi, G. Limits of the classical concept of concentration. J. Phys. Chem. B 2016, 120, 7438-7445. [CrossRef]

83. Stenlid, J.H.; Brinck, T. Extending the $\sigma$-hole concept to metals: An electrostatic interpretation of the effects of nanostructure in gold and platinum catalysis. J. Am. Chem. Soc. 2017, 139, 11012-11015. [CrossRef]

84. Cha, H.J.; Byrom, M.; Mead, P.E.; Ellington, A.D.; Wallingford, J.B.; Marcotte, E.M. Evolutionarily repurposed networks reveal the well-known antifungal drug thiabendazole to be a novel vascular disrupting agent. PLoS Biol. 2012, 10, e1001379. [CrossRef]

85. Zhang, C.; Zhong, B.; Yang, S.; Pan, L.; Yu, S.; Li, Z.; Li, S.; Su, B.; Meng, X. Synthesis and biological evaluation of thiabendazole derivatives as anti-angiogenesis and vascular disrupting agents. Bioorg. Med. Chem. 2015, 23, 3774-3780. [CrossRef]

86. Davidse, L.; Flach, W. Interaction of thiabendazole with fungal tubulin. Biochim. Biophys. Acta Gen. Subj. 1978, 543, 82-90. [CrossRef]

87. Kim, Y.; Kumar, M.R.; Park, N.; Heo, Y.; Lee, S. Copper-catalyzed, one-pot, three-component synthesis of benzimidazoles by condensation and C-N bond formation. J. Org. Chem. 2011, 76, 9577-9583. [CrossRef] [PubMed]

88. Grenda, V.J.; Jones, R.E.; Gal, G.; Sletzinger, M. Novel preparation of benzimidazoles from N-arylamidines. New synthesis of thiabendazole. J. Org. Chem. 1965, 30, 259-261. [CrossRef]

89. Bistoni, G.; Belanzoni, P.; Belpassi, L.; Tarantelli, F. $\pi$-Activation of alkynes in homogeneous and heterogeneous gold catalysis. J. Phys. Chem. A 2016, 120, 5239-5247. [CrossRef]

90. Tang, D.; Chen, Z.; Tang, Y.; Zhang, J.; Xu, Z.; Zhang, J. Investigation of the cycloisomerization of 1,6-enynes catalyzed by gold nanoparticles with first-principles calculations: Mechanism and selectivity. J. Phys. Chem. C 2014, 118, 18510-18520. [CrossRef]

91. Symeonidis, T.S.; Lykakis, I.N.; Litinas, K.E. Synthesis of quinolines and fused pyridocoumarins from $\mathrm{N}$-propargylanilines or propargylaminocoumarins by catalysis with gold nanoparticles supported on $\mathrm{TiO}_{2}$. Tetrahedron 2013, 69, 4612-4616. [CrossRef]

92. Fragkiadakis, M.; Kidonakis, M.; Zorba, L.; Stratakis, M. Synthesis of 3-keto pyridines from the conjugated allenone-alkynylamine oxidative cyclization catalyzed by supported Au nanoparticles. Adv. Synth. Catal. 2020, 362, 964-968. [CrossRef]

93. Oliver-Meseguer, J.; Boronat, M.; Vidal-Moya, A.; Concepcion, P.; Rivero-Crespo, M.A.; Leyva-Perez, A.; Corma, A. Generation and reactivity of electron-rich carbenes on the surface of catalytic gold nanoparticles. J. Am. Chem. Soc. 2018, 140, 3215-3218. [CrossRef]

94. Corma, A.; Juarez, R.; Boronat, M.; Sanchez, F.; Iglesias, M.; Garcia, H. Gold catalyzes the Sonogashira coupling reaction without the requirement of palladium impurities. Chem. Commun. 2011, 47, 1446-1448. [CrossRef]

Publisher's Note: MDPI stays neutral with regard to jurisdictional claims in published maps and institutional affiliations.

(C) 2020 by the authors. Licensee MDPI, Basel, Switzerland. This article is an open access article distributed under the terms and conditions of the Creative Commons Attribution (CC BY) license (http://creativecommons.org/licenses/by/4.0/). 